\title{
Lihavuuden ja mielenterveyden välinen yhteys
}

"Lihavuus kaikkine siihen liittyvine lisätekijöineen kuuluu yleisimpiin, eritoten länsimaista ihmistä kiusaaviin sairanksiin. Viime aikoina on meidänkin maassamme - ja syystä - alettu kiinnittää siihen ja sen vastustamiseen entistä enemmän huomiota. Lihavuuden vastustaminen muodostaa nykyisin yhden ehkäisevän lä̈ketieteen ajankohtaisimmista kysymyksistä, eikä tämä suinkaan johdu mistään muotivirtausten aiheuttamista syistä, vaan siitä, että on opittu tuntemaan ne monet vaarat, jotka uhkaavat liikapainoista ihmistä ja hänen terveyttään.”

Näin kirjoitti Helsingin yliopiston sisätautiopin dosentti Niilo Saksela lihavuudesta vuonna 1958 ilmestyneessä Suuressa Lääkärikirjassa (1). Kun löysin kirjan tapaninpäivänä 2018 isoäitini Tertun kirjahyllystä Martinlaaksossa, yllätyin, että lihavuudesta ylipäätään kirjoitettiin 1950-luvulla, ja vieläpä nykyäänkin ajankohtaiseen sävyyn. Lihavuus on nimittäin maailman historiaan suhteutettuna uusi ilmiö, joka on yleistynyt länsimaissa vasta maailmansotien jälkeen. Kautta aikojen aliravitsemus on ollut maailmassa vallitseva ravitsemusongelma. Tätä kuvaa esimerkiksi se, että vielä 1950-luvulla kemiläisiä lapsia lähetettiin paikalliseen saareen lihotusleireille kesäisin. 1970-luvulta lähtien lihavuus on maailmassa kuitenkin lähes kolminkertaistunut (2).

Maailman terveydenjärjestö WHOn mukaan lihavuus on tila, jolloin kehossa on normaalia suurempi määrä rasvakudosta, josta koituu terveydellistä haittaa (2). Ideaalin painon määrittäminen on laskennallisesti kuitenkin haastavaa. Historian aikana onkin esiintynyt monia tapoja määritellä lihavuus. Esimerkiksi Brocan kaavaan mukaan ihannepainon tulisi olla niin monta kiloa kuin ruumiinpituus senttimetreinä ylittää sadan (1). Nykyään tavallisin tapa laskennallisesti määritellä lihavuus on laskea BMI eli paino- indeksi - body mass index. Se lasketaan jakamalla paino kiloissa pituuden metreissä neliöllä. WHOn mukaan voidaan puhua ylipainosta, kun BMI on yli 25 ja lihavuudesta kun BMI on yli 30 (2). Esimerkiksi $170 \mathrm{~cm}$ pitkä ihminen luokitellaan ylipainoiseksi, kun hän painaa yli 72 kiloa ja lihavaksi kun hän painaa yli $87 \mathrm{~kg}$.

THL:n vuoden 2017 FinTerveys-raportin mukaan kaksi kolmasosaa suomalaisista naisista ja kolme neljäsosaa miehistä ovat ylipainoisia (3). Lisäksi joka neljäs nainen ja joka neljäs mies luokitellaan lihavaksi. Isoäitini isoäidin Anna-Sofian eläessä 1800-luvulla lihavuutta esiintyi lähinnä vain varakkaissa piireissä. Niinpä lihavuus nähtiin merkkinä vauraudesta. 1950-luvulla suhtautuminen oli kuitenkin jo muuttunut, sillä tiedettiin, että kehon paino on yhteydessä kuolleisuuteen ja on terveysriski, jota tulisi yrittää ennaltaehkäistä ja hoitaa (1). Jo Suuren Lääkärikirjan ilmestyessä tiedettiin, että lihavuus on yhteydessä muun muassa verenpainetautiin, sokeritautiin, valtimokovettumiseen, sappiteiden sairauksiin ja infektiotauteihin. Nykyään lihavuuden riskitekijöistä tiedetään vielä enemmän. On osoitettu, että lihavuus on yhteydessä myös muun muassa useaan syöpään, maksan sairauksiin, tuki- ja liikuntaelinten sairauksiin, uniapneaan, muistisairauksiin ja astmaan (4).

1950-luvun Suuressa Lääkärikirjassa ei suoranaisesti mainita, että lihavuus olisi yhteydessä mielenterveyshäiriöihin, mutta lihavuuden syitä punnittaessa nostetaan esille sielullisten tekijöiden osuus. Tätä perusteltiin sillä ajatuksella, että ihmiset saattavat reagoida erilaisiin vastuksiin ja vastoinkäymisiin kompensoimalla ristiriitojaan liikasyömisellä, mikä aiheuttaisi lihavuutta (1).

Käytännöllisesti katsoen kuitenkin nähtiin, kuten nykyään, että lihavuus on seuraus ravinnon kalorimäärän ja energiantarpeen välisestä epäsuhteesta. Jos monimutkaisesta asiasta tekee helpon, voisi sanoa, että lihavuus maailmassa on 
yleistynyt sillä ruokamme on energiatiheämpää ja helpommin saatavilla kun ennen, samanaikaisesti kun arjesta on tullut fyysisesti vähemmän kuormittavaa ja työstä fyysisesti kevyempää teknologisen kehityksen myötä. Vaikka vapaa-ajan liikuntaa harrastetaan aiempaa enemmän, ei se kuitenkaan kompensoi päivittäistä istumista ja arjen liikkumattomuutta. Jos asiasta haluaa tehdä monimutkaisemman, niin voi tietysti lisätä, että hormonaalisilla, perinnöllisillä ja tulehduksellisilla tekijöillä sekä muun muassa suoliston bakteereilla on oma vaikutuksensa lihavuuden syntyyn $(5,6)$.

Toisin kuin lihavuudesta, mielenterveydestä tiedettiin hyvin vähän 50-luvulla. Suuressa Lääkärikirjassa on sivukaupalla tekstiä sielullisista sairauksista, hysteriasta, neurasteniasta ja heikkohermoisuudesta, mutta nykyään jo kansantaudiksi luokiteltavasta masennuksesta löytyy tietoa vain puolikas sivu (1). Onneksi kehitys tieteen maailmassa ja yhteiskunnassamme on ollut huikeaa ja ymmärryksemme terveyden moniulotteisuuteen on lisääntynyt. Nykyään on itsestään selvää, että mielenterveys on tärkeä osa kokonaisvaltaista terveyttä ja, että mielenterveyshäiriöt ovat sairauksia muiden sairauksien joukossa. "There is no health without mental health", on WHOn lanseeraama tunnuslause (7).

Mielenterveydenhäiriöt ovat väestössä yleisiä - on arvioitu, että joka kolmas sairastuu mielenterveyshäiriöön elämänsä aikana. FinTerveys 2017- tutkimuksen mukaan suomalaisilla naisista kahdeksalla prosentilla ja miehistä kuudella prosentilla on vuoden aikana todettu masennus (3). Lisäksi joka viidennellä naisella ja joka kuudennella miehellä oli vuoden aikana ollut masennusoireita.

Elämään kuuluu ylä- ja alamäkiä, mutta mikäli mielenterveysoireet pitkittyvät ja aiheuttavat toimintakyvyn heikentymistä, niin voidaan oireiden taustalla epäillä mielenterveyshäiriötä. Mielenterveyden osalta diagnostiikka perustuu pääasiassa haastatteluun ja muiden sairauksien poissulkuun. Euroopassa on mielenterveyshäiriöiden diagnostiikkaan käytössä ICD-10-kriteerit (8). ICD-10-kriteereissä on jokaista mielenterveyshäiriötä kohden tietyt, sovitut diagnoosikriteerit, joiden täytettyä voidaan puhua mielenterveyshäiriöstä. Mielenterveyden osalta diagnostiikka on haastavampaa kuin niiden sairauksien osalta, joita voidaan todeta laboratoriokokeilla tai röntgenlöydöksillä. On hyvä pitää mielessä, että todellisuudessa on olemassa laaja skaala oireita ja, että sairauden ja terveyden välinen raja on asiantuntijoiden keskenään sopimaa.

Suuren Lääkärikirjan mukaan masennuksen ajateltiin johtuvan vaikeasta vastoinkäymisestä tai suuresta surusta (1). Lääketieteellisen kehityksen myötä ymmärryksemme etenkin mielenterveydenhäiriöiden biologiseen puoleen on lisääntynyt. Nykytutkimuksen ja kuvantamismenetelmien avulla olemme oppineet, että useassa mielenterveydenhäiriössä on havaittavissa muutoksia muun muassa aivojen välittäjäaineissa ja aivosolujen toiminnassa. Markkinoille on ilmestynyt tiheään tahtiin uusia psyykenlääkkeitä ja myös ei-lääkkeellisiä hoitoja, etenkin terapiamuotoja on kehitelty (9). Myös diagnostiikka on tarkentunut ja apua on saatavilla sekä sitä haetaan aiempaa herkemmin.

Lihavuus ja mielenterveysongelmat ovat nykyään keskeisimpiä kansanterveyden haasteitamme. Molemmat ovat yhteydessä somaattisiin sairauksiin, huonoon toimintakykyyn ja työkyvyttömyyteen $(4,9)$. Tutkimuksissa on osoitettu, että lihavuuden ja mielenterveyden välillä on yhteys (10), mutta yhteyden suuntaa ja sen merkitystä työikäisessä väestössä ei tunneta kovin hyvin. Lihavuuden ja mielenterveyden kausaalisuhdetta eli yhteyttä ajallisesti muna-vai-kana -asetelmalla on haastavaa tutkia. Esimerkiksi masennuksen oireisiin kuuluu ruokahalun muutos, johon liittyy painon lasku tai painon nousu. Tämän lisäksi useat mielenterveydenhäiriöiden hoidossa käytetyt lääkkeet saattavat vaikuttaa ruokahaluun ja painoon (11).

Pitkittäistutkimuksissa on kuitenkin päätelty, että yhtäältä lihavuus lisää riskiä sairastua mielenterveyshäiriöihin ja toisaalta mielenterveyshäiriöt lisäävät riskiä lihavuudelle (12). Kaikissa tutkimuksissa tulokset eivät kuitenkaan ole olleet samansuuntaisia - joissakin tutkimuksissa yhteyttä ei ole löytynyt ja toisissa on havaittu, että esimerkiksi lihavuuden yhteys mielenterveyshäiriöihin on vahvempi naisilla ja nuorilla kuin miehillä ja iäkkäämmillä.

Työterveyden alan tutkimuksista tiedetään, että lihavuus on yhteydessä heikentyneeseen fyysiseen toimintakykyyn, sairauspoissaoloihin ja työkyvyttömyyseläkkeisiin $(13,14,15)$. On muutamia tutkimuksia, joissa työkyvyttömyyden syitä on tarkasteltu tarkemmin sairausryhmittäin. 
Näissä tutkimuksissa on havaittu lihavuuden lisäävään riskiä tuki- ja liikuntaelinsairauksista johtuville sairauspoissaoloille ja työkyvyttömyyseläkkeille, mutta mielenterveyden osalta tulokset ovat vaihdelleet $(14,15)$. Joissakin tutkimuksissa on havaittu yhteys lihavuuden ja mielenterveyshäiriöistä johtuvien sairauspoissaolojen ja työkyvyttömyyseläkkeiden välillä, mutta toisissa tutkimuksissa yhteyttä ei olla havaittu, tai yhteys on kadonnut, kun on huomioitu fyysiseen terveyteen liittyviä tekijöiltä.

Etenkin 1990-luvulta lähtien mielenterveyshäiriöt työkyvyttömyyden taustalla ovat lisääntyneet huolestuttavasti. Vuodesta 2000 mielenterveyshäiriöt ovat olleet suurin työkyvyttömyyseläkkeitä aiheuttava sairausryhmä Suomessa (16). Vuonna 2017 mielenterveyshäiriöt aiheuttivat kaksi viidesosaa (42\%) työkyvyttömyyseläkkeistä ja tuki- ja liikuntaelinten sairaudet aiheuttivat neljäsosan $(26 \%)$ työkyvyttömyyseläkkeistä (16). Myös Kelan yli kymmenen päivää kestävän sairauspoissaolon syynä oli neljäsosalla (26\%) mielenterveyshäiriöt ja kolmanneksella (32\%) tuki- ja liikuntaelinten sairaudet (17). Työelämä on muuttunut kovaa vauhtia muun maailman kehityksen myötä ja työn kuormittavuus on yhä useammin siirtynyt fyysisestä kuormituksesta psykososiaaliseen kuormittavuuteen. Tämä saattaa osittain - muttei kokonaan - selittää sitä, että työkyvyttömyys mielenterveyssyistä on lisääntynyt. Jotta työkyvyttömyyttä voitaisiin ennaltaehkäistä, olisi tärkeätä lisätä ymmärrystä niitä syitä kohtaan jotka mahdollisesti ovat kehityksen taustalla.

Koska Suomessa väestö ikääntyy ja syntyvyys on alhainen, on tärkeää, että työikäinen väestö pysyy terveenä ja toimintakykyisenä. Koska lihavuutta on hyvin vaikeaa hoitaa, on tärkeätä yrittää ennaltaehkäistä painon nousua ja löytää tekijöitä, jotka ylläpitävät työ- ja toimintakykyä ylipainoisilla. Tällaista tutkimustietoa ja ymmärrystä voidaan hyödyntää sairauksien ehkäisemisessä ja työ- ja toimintakyvyn ylläpitämisessä. Tämän takia väitöskirjatyön tavoitteena oli lisätä ymmärrystä lihavuuden yhteydestä työ- ja toimintakykyyn yleisesti sekä erityisesti mielenterveydenhäiriöiden osalta.

\section{LÄHTEET}

(1) Saksela N. Ravitsemus ja ravitsemushäiriöt. Kirjassa: Saksela N. (päätoim) Suuri Lääkärikirja. 4. p. Porvoo: Werner Söderström osakeyhtiö; 1958

(2) World Health Organization. Obesity and overweight: key facts. Luettu 15.8.2018. http:// www.who.int/news-room/fact-sheets/detail/ obesity-and-overweight

(3) Koponen P, Borodulin K, Lundqvist A ym. (toim.) Terveys, toimintakyky ja hyvinvointi Suomessa - FinTerveys 2017-tutkimus. Terveyden ja hyvinvoinnin laitos (THL). Raportti 4/2018. http://urn.fi/ URN:ISBN:978-952-343-105-8

(4) Lihavuus (aikuiset). Käypä hoito -suositus. Suomalaisen Lääkäriseuran Duodecimin ja Suomen Lihavuustutkijat ry:n asettama työryhmä. Helsinki: Suomalainen Lääkäriseura Duodecim, 2013 (viitattu 12.4.2019). Saatavilla internetissä: www.kaypahoito.fi

(5) Million M, Lagier J. C., Yahav D ym. Gut bacterial microbiota and obesity. Clin Microbiol Infect. 2013;19:305-13. doi: 10.1111/1469-0691.12172.

(6) Albuquerque D, Stice E, Rodríguez-López $\mathrm{R} y \mathrm{ym}$. Current review of genetics of human obesity: from molecular mechanisms to an evolutionary perspective. Mol Genet Genomics. 2015;290:1191-221.

doi: 10.1007/s00438-015-1015-9

(7) World Health Organization. Mental health: facing the challenges, building solutions. Report from the WHO European Ministerial Conference. Copenhagen, Denmark: WHO Regional Office for Europe; 2005.

(8) Terveyden ja hyvinvoinnin laitos. Psykiatrian luokituskäsikirja. Tautiluokitus ICD-10:n psykiatriaan liittyvät diagnoosit. Luokitukset, termistöt ja tilasto-ohjeet 1/2012. Tampere: Terveyden ja hyvinvoinnin laitos; 2012.

(9) Depressio. Käypä hoito -suositus. Suomalaisen Lääkäriseuran Duodecimin ja Suomen Psykiatriyhdistys ry:n asettama työryhmä. Helsinki: Suomalainen Lääkäriseura Duodecim; 2016 (viitattu 12.4.2019). Saatavilla internetissä: www.kaypahoito.fi

(10) Rajan TM, Menon V. Psychiatric disorders and obesity: A review of association studies. J Postgrad Med. 2017;63:182-190. doi:10.4103/jpgm.JPGM_712_16

(11) Dent R, Blackmore A, Peterson J ym. Changes in body weight and psychotropic drugs: a systematic synthesis of the literature. PLoS One. 2012;7:e36889. doi: 10.1371/journal.pone.0036889.

(12) Mannan M, Mamun A, Doi S ym. Is there a bi-directional relationship between depression and obesity among adult men and women? Systematic review and bias-adjusted meta analysis. Asian J Psychiatr. 2016;21:51-66. doi: 10.1016/j.ajp.2015.12.008. 
(13) Svärd A, Lahti J, Roos E ym. Obesity, change of body mass index and subsequent physical and mental health functioning: a 12-year follow-up study among ageing employees. BMC Public Health. 2017;17:744.

doi: 10.1186/s12889-017-4768-8.

(14) Svärd A., Lahti J., Mänty M ym. Weight change among normal weight, overweight and obese employees and subsequent diagnosis-specific sickness absence: a register linked follow-up study. Scand J Public Health. 2018 Sep 29. doi: 10.1177/1403494818802990.

[Epub ahead of print]

(15) Svärd A., Pipping, H., Lahti J ym. Joint association of overweight and common mental disorders with diagnosis-specific disability retirement: a follow-up study among female and male employees. J Occup Environ Med. 2018 Jul 16.

doi: 10.1097/JOM.0000000000001409.

(16) Eläketurvakeskus. Suomen työeläkkeensaajat 2017. Eläketurvakeskuksen tilastoja 07/2018. Suomen virallinen tilasto: Sosiaaliturva 2018. http://urn.fi/URN:NBN:fi-fe2018062826566
(17) Kansaneläkelaitos. Kelan tilastollinen vuosikirja 2017. Suomen virallinen tilasto: Sosiaaliturva 2018. Helsinki: Kansaneläkelaitos. http://urn.fi/ URN:NBN:fi-fe2018120349699

Lääketieteen lisensiaatti Anna Svärdin väitöskirja Body weight and mental health: a follow-up study on health functioning and work disability (Kehon paino ja mielenterveys: seurantatutkimus toimintakyvystä ja työkyvyttömyydestä) tarkastettiin Helsingin yliopiston lääketieteellisessä tiedekunnassa 15.3.2019. Vastaväittäjänä toimi professori Clas-Håkan Nygård Tampereen yliopistosta ja kustoksena professori Ossi Rabkonen Helsingin yliopistosta.

\section{ANNA SVÄRD}

$L T$

Helsingin yliopisto

Kansanterveystieteen osasto 